\title{
Regulation of tax debt
}

Marina E. Orlova ${ }^{1}$, Farida F. Adigamova ${ }^{2}$, Kseniya B. Valiullina ${ }^{3}$, Igor G. Nikitenko ${ }^{4}$

${ }_{1,2,3,4}$ Kazan Federal University, 18 Kremlyovskaya str. Kazan, 420008

Received: 21st October 2017 Accepted: 16th November 2017, Published: 31st December 2017

\begin{abstract}
The article is devoted to the adjustment of the legal base for collection of tax debts; as well as approaches to identifying uncollectible tax debts. The historical aspects of the legal framework formation for the settlement of uncollectible debts in Russia are determined. The structure of taxation is analyzed. The possibilities of taxpayers' abuse of existing mechanisms for writing off tax debts have been explored. An analysis was made for the standard uncollectible tax debts. Emphasis was placed on the regulatory framework of the rules for recognition and relief of debts, fines and penalties on taxes. Ineffectiveness of the institution of bankruptcy was revealed. Norms were presented to prevent bankruptcy by organizing financial monitoring of the conditions available in an organization. This paper also focuses on restoring documents to tax authorities from taxpayers, their contractors, and conducting tax audits.
\end{abstract}

Keywords: Inadequate Execution of a Tax Duty, Uncollectible Tax Debt, Institute of Bankruptcy, Collecting Tax Debt.

\section{Introduction}

Failure to fulfill or improper fulfillment of the obligation to pay taxes and fees is the basis for applying the mechanism of enforced collection of tax debts on the part of the state [13. Thomson, W. ]. At the same time, an effective legal mechanism for ensuring tax payments, on the one hand, implies the effective collection of tax payments that were not timely received by the treasury, and the corresponding penalties and fines, and, on the other hand, should be aimed at guaranteed compliance with the inalienable rights and economic freedoms of taxpayers enshrined in the Constitution of the Russian Federation. At the same time, the current mechanism for collecting tax payments is characterized by a significant amount of tax debt.

An important factor is the use of illegal schemes to avoid paying taxes. Thus, the analysis of economic activities of legal entities registered in our country allows us to say that more than $40 \%$ of those organizations are created to participate in schemes of tax evasion, schemes for legalization and withdrawal of assets abroad. [9. Nejadmalayeri, A. Singh, M. ] Of course, one of the reasons for this situation is the absence of real legal barriers to the creation of such entities and, first of all, legislation on registration.

\section{Theory}

Currently, the recognition of debts in the payment of taxes, fees, penalties and fines (tax arrears) as uncollectible and subject to write-off are regulated by Art. 59 of the Tax Code of the Russian Federation. It has been established there that the arrears attributed to individual taxpayers, payers of levies and tax agents, payment and recovery of which were impossible for economic, social or legal reasons, is considered to be uncollectible and written off in the manner established by the Government of the Russian Federation in respect of federal taxes and fees, as well as executive bodies of state power of the constituent entities of the Russian Federation, and local administrations in respect of regional and local taxes.

Writing-off of the uncollectible tax arrears prior to 2010 was carried out according to the Resolution of February 12, 2001. No. 100 "On the procedure for recognizing uncollectible and writing-off of deficiencies and arrears of fines and penalties on federal taxes and fees, as well as debts on insurance contributions to state social extra-budgetary funds, accrued penalties and fines" [1].

Despite the fact that Resolution No. 100 established only the rules for recognizing and writing-off of deficiencies and arrears on fines and penalties for federal taxes and levies, and the list of documents required for such write-off was uniform for all cases, the practical application of the provisions of the Resolution No. 100 repeatedly became the subject of judicial review. In connection with the outstanding issues contained in Resolution No. 100, Order No. YAK-7-8 / 393 @ of the Federal Tax Service of Russia dated August 19, 2010, a new procedure for writing off the deficiencies and arrears for fines, penalties and interest recognized as uncollectible, and the list of documents confirming the circumstances of recognition as uncollectible deficiencies and arrears on penalties, fines and interests have been approved [2].

In 2015, the Federal Tax Service of Russia amended the procedure for writing off deficiencies and arrears of fines, penalties and interest that are considered to be uncollectible. The corresponding order of the Federal Tax Service of Russia dated 19.05.2015 No. MMV-7-8 / 200 @ entered into force on June 29, 2015. This is an arrear the recovery of which was impossible in the case when a bailiff makes a decision on the termination of the enforcement proceedings, if the date of arrear formation is more than five years. 
Prior to that, the arrear was considered to be uncollectible due to the termination of the enforcement proceedings, if five years have expired since the date of its formation. In addition, the list of documents confirming the circumstances of recognition deficiencies and arrears on penalties, fines and interest as uncollectible was adjusted.

Upon rendering a decision on the termination of the enforcement proceedings by the bailiff when the execution document returns to the recoverer, if more than five years have expired since the date of the deficiencies or arrears of fines and penalties occur, the supporting documents should be:

1) a copy of the decision of the bailiff on the termination of the enforcement proceedings when the enforcement document returns to the recoverer;

2) a certificate of the tax authority at the place of registration of the organization (place of residence of an individual) on the amounts of deficiencies and arrears on penalties, fines and interests;

3) decision of the court on return of a bankruptcy petition or for stopping the bankruptcy proceedings due to the lack of sufficient funds to reimburse court costs for procedures. Earlier in this list, the first two items were listed: the bailiff's decision and a certificate from the tax authority.

Upon determining the facts of abuse by a taxpayer, the tax authorities use the Resolution of the Plenum of the Supreme Arbitration Court of the Russian Federation dated October 12, 2006. N 53 "On Evaluation by Arbitration Courts of the Justification of Receiving a Tax Benefit by a Taxpayer". However, the existing court practice does not provide for all possible cases of abuse by taxpayers of their rights and does not allow the tax authorities to fully use all opportunities to combat aggressive tax planning [6. Cloyne, J.S. Surico, $\underline{P}$.$] . In this regard, we propose additional standards$ aimed at combating the use of illegal schemes for evasion of the payment of tax arrears.

\section{Results}

The tax authorities have no opportunity to prove the use of illegal schemes because of the imperfection of the legislative base. It is problematic to prove in practice the use of such schemes as deliberate bankruptcy, cooperation with "one-day" firms, illegal dissolution of organizations, as well as concealment of the tax base. So the refusal to initiate criminal cases for tax crimes is approximately $70 \%$, and in some regions $90-95 \%$ at all, what indicates a lack of an evidence base provided by tax authorities.

We consider the most promising to include into the Tax Code of the Russian Federation the right to increase the number of inspections conducted jointly with the police [12, Sorensen, P.B.]. Also, an effective form of tax control is the rechecking of enterprises that have allowed the concealment of taxes in large amounts within a year from the time of such concealment. Similar repeated checks allow checking the performance of enterprises under the act of the previous inspection, as well as the reliability of the current accounting. The effectiveness of control significantly increases when applying cross checks, the essence of which is a visit of employees of departments from one tax office to the territory of another office.

The largest share in the uncollectible tax arrear belongs to the arrear of the liquidated organizations (3618 million rubles), what once again confirms the ineffectiveness of the institution of bankruptcy [7, Grant, C., Koeniger, W.], as well as the massive use of schemes with reorganization, mergers, acquisitions of organizations, as well as the sale of organizations to offshore companies in order to avoid paying tax arrears, as shown in Figure 1.

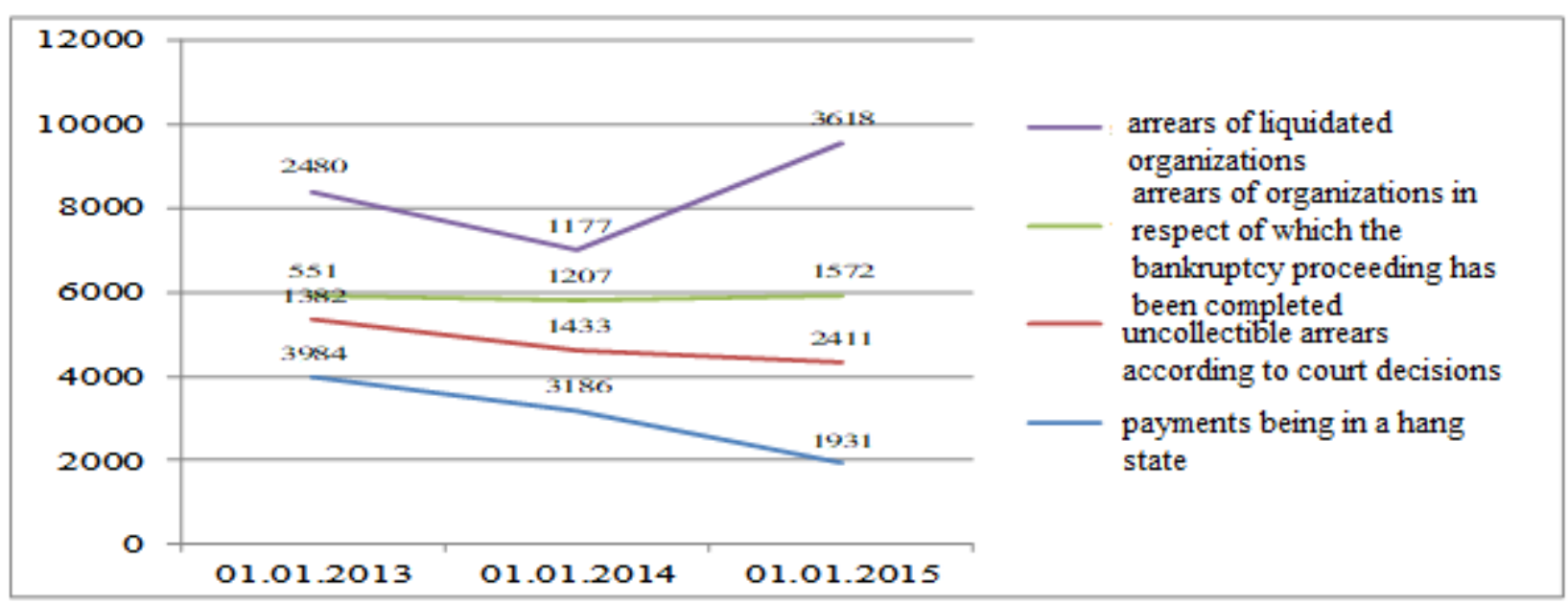

Fig. 1. Specific weight of tax arrear types in the uncollectible tax arrears of organizations for $2013-2015$, in million rubles. ${ }^{1}$

\footnotetext{
${ }^{1}$ Based on tax inspection reporting [4] 
It is required to improve the rules that governing bankruptcy which has the greatest impact on tax arrears. Bankruptcy must be prevented through the organization of financial monitoring of the state of affairs both in each organization and the industry as a whole, development of an anti-crisis management mechanism, closing unprofitable productions and predicting bankruptcies of insolvent and unprofitable organizations [15, Yang, J. -Q, Yang, Z. -J].
It is necessary to develop tax norms for conducting the diagnostics of bankruptcy and anti-crisis regulation, which will prevent an increasing number of bankruptcies [9, Nejadmalayeri, A., Singh, M.], will avoid the dissolution of many enterprises that have a large impact on the level of tax arrears in the Russian Federation as a whole. An example of the organization dissolution scheme is shown in Figure 2 [3].

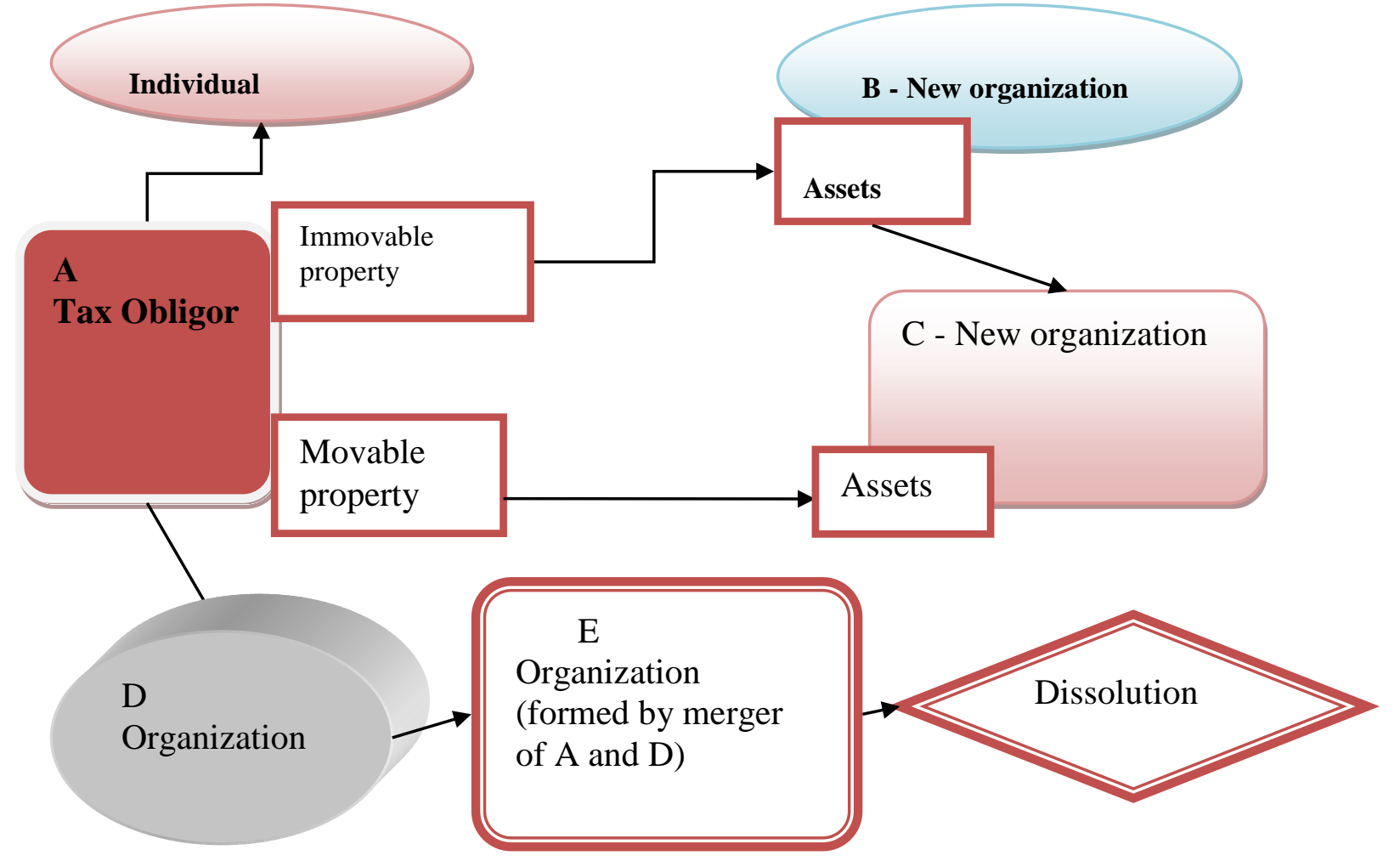

Fig. 2. Organization dissolution scheme

Stages of creation of the organization dissolution scheme:

1) Organization A creates organization $B$ and brings movable property into it, making a contribution to the authorized capital;

2) The share of tax obligor $A$ in organization $\mathrm{C}$ is alienated to individuals which thus become participants in the new organization;

3) The organization A also creates a new organization B and moves out real estate in it, making a contribution to the authorized capital;

4) The share of the tax obligor $A$ in the organization $\mathrm{B}$ is alienated to individuals which thus become participants in this organization. Subsequently, organization $\mathrm{B}$ sales to the organization $\mathrm{C}$ the real property under a contract of sale.
5) Then the tax obligor $A$ is merged with the organization D and creates a new organization $\mathrm{E}$, to which all obligations to the budget should be passed, including the amounts of the restored VAT when transferring contributions to the authorized capital together with arrears to the budget.

6) Organization $\mathrm{E}$ is dissoluted together with arrears to the budget.

As a result of the transformation, all assets (movable and immovable property) of the organization $\mathrm{A}$ are transferred to the organization $\mathrm{C}$ which has practically the same name, and the founders of which are individuals. All arrears to the budget are transferred to the organization $G$, which is dissoluted together with arrears. In this case, the arrears of the organization $G$ will be recognized as uncollectible to recovery. 
The largest share in the uncollectible tax arrears that belongs to the arrears of liquidated organizations (3,618 million rubles), what, as well as the massive use of schemes with reorganization, merger and acquisition [11, Roin, J.A.], and the sale of organizations to offshore companies in order to avoid paying tax arrear, as shown in Figure 1, once again confirms the ineffectiveness of the institution of bankruptcy.
It is required to work out the basic norms of legislation on the issue of bankruptcy, which has the greatest impact on tax arrear with a term of formation over 36 months. These norms should concern the prevention of bankruptcy through the organization of financial monitoring of the state of affairs, the perfect mechanism of crisis management, closure of unprofitable productions and the forecasting of bankruptcies of insolvent and unprofitable organizations [14, Thomson, W.].

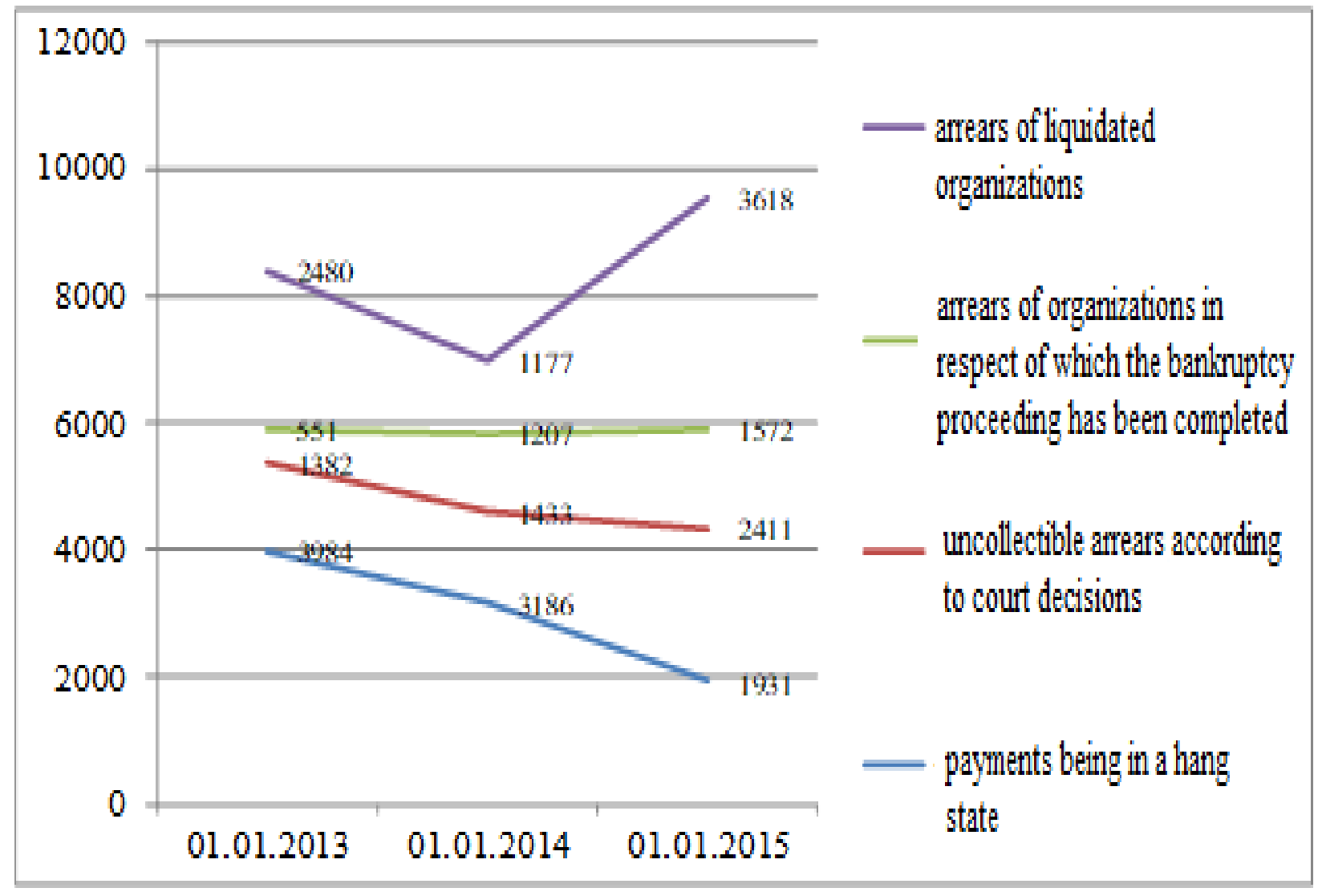

Fig. 1. Specific weight of tax arrears by types in the uncollectible tax arrears of organizations for $2013-2015$, in million rubles ${ }^{2}$

\footnotetext{
${ }^{2}$ Based on tax inspection reporting [4] 
As of January 1, 2015, uncollectible tax arrears have decreased by $25 \%$ compared to 2011 . Sufficient weight in the structure of arrears with a maturity of more than 3 years is the arrears of organizations recognized as bankrupt. Despite its decrease, it remains quite significant: it is almost 11 billion rubles.

Decrease in uncollectible tax arrears indicates that the number of dissoluted organizations has decreased, and that the tax authorities have begun to collect arrears on time, namely, before the expiry of the statute of limitations.

In connection with the decrease in the uncollectible tax arrear amount, the share of the budget losses also decreased by $13.19 \%$. The highest share of budget loss pertains to 2012, amounting to $42.34 \%$. At present, the situation of reducing uncollectible arrears is in a state of stability. However, it should be noted that to date the normative acts are not sufficiently effective to reduce arrears.

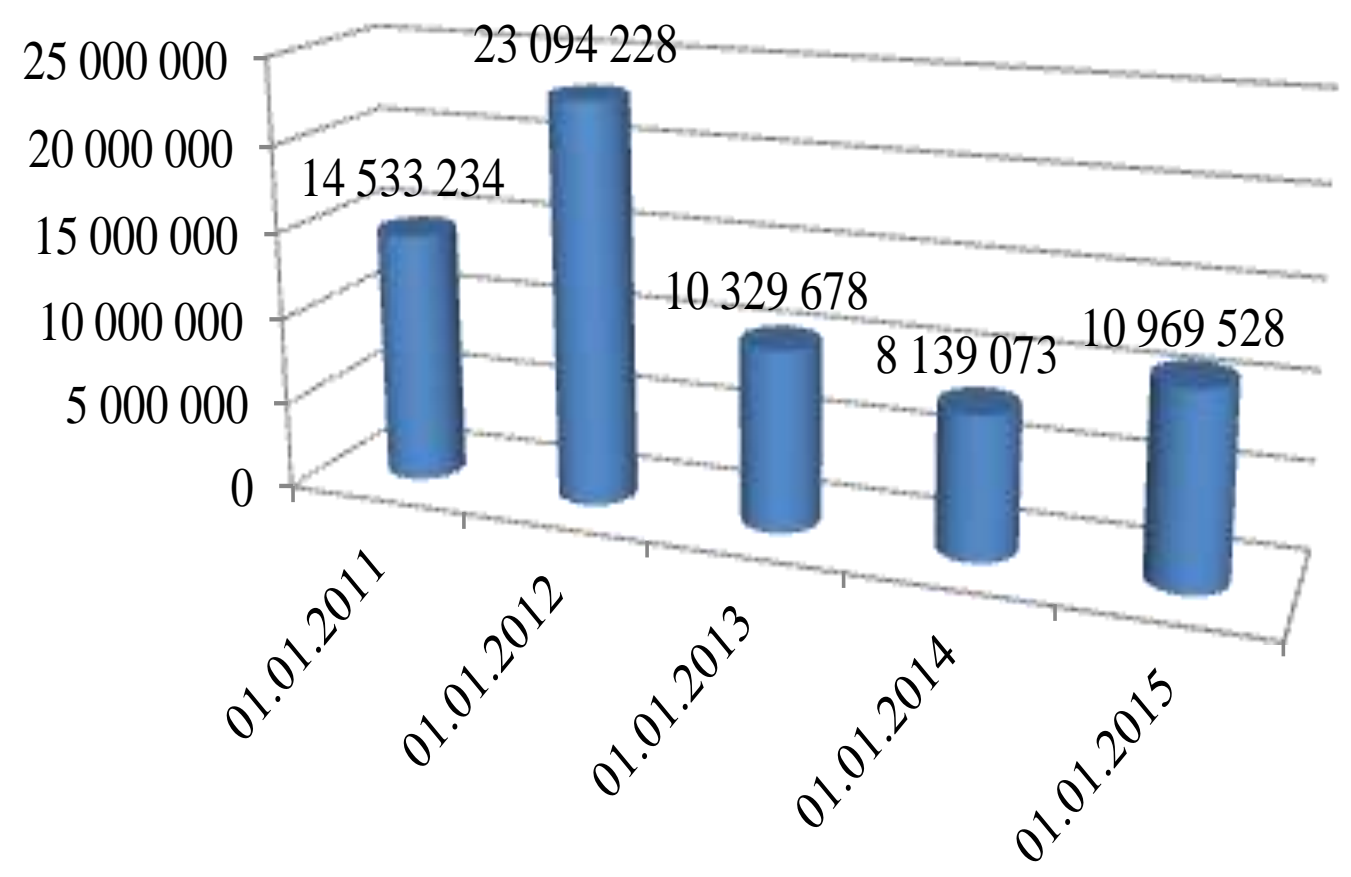

Fig. 3. Change in the amount of uncollectible tax arrears of organizations in the period from 2011 to $2015^{3}$

\footnotetext{
${ }^{3}$ Based on tax inspection reporting [4] 
Article 59 of the Tax Code of the Russian Federation contains special norms on recognition of deficiencies both impossible to recover due to economic, social, or legal reasons and its recognition as uncollectible. The decision on recognizing an arrear as uncollectible and its writing off is taken by the head of the tax authority at the location of the organization.

The norms of tax law do not fully reflect the current practice and require significant additions. It can be argued that the largest share in the tax arrears that are impossible to collect belongs to the arrears of the dissoluted organizations and the massive use of dissolution schemes for organizations, what once again confirms the ineffectiveness of the bankruptcy institution [10, Platikanova, P.]. At the same time, since tax arrear is recognized as uncollectible, it is subject to write-off, thus the budget loses a certain share of cash, and money are spent for the introduction of bankruptcy procedures before the dissolution of an organization [5, Bonsall, S.B. Koharki, K., Watson, L.].

\section{Discussion}

The procedures for collecting tax arrears in Russia, established by the tax legislation and bankruptcy legislation, are unified throughout Russia. The legal regulation of these procedures should take into account both the financial interests of the state, i. e. effective collection of tax payments, penalties and fines that have not been received in time, and observance of the rights and economic freedoms of taxpayers.

A great influence on the formation of tax arrears is caused by the application of tax schemes for tax evasion. The analysis showed that more than $40 \%$ of legal entities registered in Russia are created to participate in schemes of tax evasion, and in schemes for legalization and withdrawal of assets abroad. One of the tax evasion schemes is deliberate bankruptcy. It can be argued that the largest share in the tax arrear that is impossible to collect is the arrear of the dissoluted organizations (3,618 million rubles) and the massive use of dissolution schemes for organizations, what once again confirms the ineffectiveness of the institution of bankruptcy.

Tax authorities do not always manage to prove facts of illegal schemes of tax evasion, in particular, it is problematic to prove facts of deliberate bankruptcy, cooperation with "one-day" firms, illegal dissolution of organizations. The reason for this is the imperfection of the tax legislation, and the absence of clear signs of these facts.

There is a positive trend in the structure of Russia's tax arrears: a decrease in the uncollectible tax arrears for the period from 2012 to 2015 . The budget losses decreased by $13.19 \%$. At the same time, the normative acts applied in Russia are not currently effective enough to reduce arrears.

Also, the legal institute for collecting tax arrears does not contain norms for the participation of guilty officials and owners of organizations in repayment of such arrears.

\section{Conclusion}

We consider it expedient to fix the need for notifying the tax authorities to the foreign organizations contributing to the authorized capital of Russian organizations. Often this is the first step towards the illegal dissolution of an organization with tax arrears with the help of offshore companies [8, Mazhar, U., Méon, P. -G.], and in case of notifying the tax authorities, they will have the opportunity to prevent the use of such illegal schemes.

It is proposed to consolidate legislatively the prevention of bankruptcy by organizing financial monitoring of the state of affairs, both in each organization and in the industry as a whole, developing an anti-crisis management mechanism, closing unprofitable industries, and predicting bankruptcies of insolvent and unprofitable organizations.

It is necessary to clarify the norms of Russian tax legislation with respect to the procedure for collecting tax arrears at the expense of officials and owners of organizations.

It is necessary to consolidate legislatively in the Tax Code of the Russian Federation the demand for documents by the tax authorities both from taxpayers and their counterparties beyond tax audits, with a view to monitoring their financial situation. The regulatory framework, which will allow for the diagnosis of bankruptcy and anti-crisis regulation will prevent an increasing number of bankruptcies, would help to avoid the dissolution of many enterprises, what has a big impact on the level of tax arrears in the Russian Federation as a whole.

\section{Acknowledgments}

The work is carried out according to the Russian Government Program of Competitive Growth of Kazan Federal University.

\section{References}

[1] Decree of the Government of the Russian Federation dated February 12, 2001. No. 100 "On the procedure for recognizing uncollectable the arrears and the write-off of deficiencies and arrears on penalties and fines for federal taxes and fees" (as amended by the Decrees of the Government of the Russian Federation dated 15.08.2002 N 602, dated 25. 11. 2004 N 678, dated 04. 11. 2006 N 652)

[2] Order of the Federal Tax Service dated August 19, 2010. N YAK-7-8 / 393 @ "On approval of the procedure for writing off the deficiencies and arrears of fines, penalties and interestы recognized as uncollectible, and the list of documents confirming the circumstances of recognition as uncollectible of deficiencies and arrears of fines, penalties and interests".

[3] Nekipelova A.D. Russian crisis and rationalization of economic strategy / A.D. Nekipelov // Russian economic journal. - 2014.

[4] Official site of the Federal Tax Service of Russia [Digital source]. Access mode: https://www. nalog. ru 
[5] Bonsall, S.B. Koharki, K. Watson, L. Deciphering Tax Avoidance: Evidence from Credit Rating Disagreements Contemporary Accounting Research 2017

[6] Cloyne, J.S. Surico, P. Household debt and the dynamic effects of income tax changes Review of Economic Studies Volume 84, Issue 1, 2017, Pages 4581

[7] Grant, C. Koeniger, W. Redistributive taxation and personal bankruptcy in U.S. states Journal of Law and Economics Volume 52, Issue 3, August 2009, Pages 445-467

[8] Mazhar, U. Méon, P.-G. Taxing the unobservable: The impact of the shadow economy on inflation and taxation World Development Volume 90, 1 February 2017, Pages 89-103

[9] Nejadmalayeri, A. Singh, M. Corporate taxes, strategic default, and the cost of debt Journal of Banking and Finance Volume 36, Issue 11, November 2012, Pages 2900-2916

[10] Platikanova, P. Debt Maturity and Tax Avoidance European Accounting Review Volume 26, Issue 1, 2 January 2017, Pages 97-124
[11] Roin, J.A. Retroactive taxation, unfunded pensions, and shadow bankruptcies Iowa Law Review Volume 102, Issue 2, January 2017, Pages 559-604 [12] Sorensen, P.B. Taxation and the optimal constraint on corporate debt finance: why a comprehensive business income tax is suboptimal International Tax and Public Finance 17 November 2016, Pages 1-23

[13] Thomson, W. Axiomatic and game-theoretic analysis of bankruptcy and taxation problems: A survey Mathematical social sciences Volume 45, Issue 3, July 2003, Pages 249-297

[14] Thomson, W. Game-theoretic analysis of bankruptcy and taxation problems: Recent advances International Game Theory Review Volume 15, Issue 3, September 2013, Article number 1340018

[15] Yang, J.-Q. Yang, Z.-J Optimal consumption, investment and bankruptcy protection Xitong Gongcheng Lilun yu Shijian/System Engineering Theory and Practice Volume 33, Issue 4, April 2013, Pages 853-860 